\title{
Boekbespreking
}

\section{HOOG ingezet}

Scheele F, Schutte MF, editors. Curriculum opleiding tot gynaecoloog op basis van het NVOG-project Herziening Opleiding Obstetrie en Gynaecologie. Utrecht: Nederlandse Vereniging voor Obstetrie en Gynaecologie; 2005. 116 pagina's. ISBN: 90-78097-01-9.

Onlangs kreeg ik het boekje over de herziening van de opleiding tot gynaecoloog in de bus, kortweg HOOG genoemd (Herziening Opleiding Obstetrie en Gynaecologie). Als onderwijskundige volg ik met aandacht de veranderingen in de vervolgopleidingen. Met de Tweede Fase en het Studiehuis nog vers in het geheugen, weet ik hoe moeilijk het is min of meer opgelegde veranderingen door te voeren. Mijn pessimisme - duidelijk het resultaat van beroepsdeformatie - kreeg het echter na het lezen van het HOOGrapport zwaar te verduren. Enig enthousiasme kon ik niet onderdrukken.

De belangrijkste reden voor mijn enthousiasme is dat HOOG erin geslaagd is onderwijskundige theorie te vertalen in voor de beroepsgroep begrijpelijke inhoud en aanpak van onderwijs en toetsing. Onderwijskundigen zien graag dat onderwijs gericht wordt op oefening van voor het vakgebied relevante taken.Vandaar de nadruk op het competentiebegrip en de aggregatie daarvan in relevante rollen voor de beroepsuitoefening. Het Centraal College Medische Specialismen (CCMS) heeft gekozen voor de Canadese CANmeds-rollen, maar er zijn meer van dergelijke competentie-indelingen die allemaal min of meer dezelfde zaken benadrukken. Typerend voor alle indelingen is dat competenties benadrukt worden die verder gaan dan de medische of klinische expertise. Meer algemene competenties zoals samenwerken, maatschappelijk handelen en communicatie worden benadrukt. Juist op deze gebieden wordt nogal eens geklaagd door de 'afnemers' van onze opleidingen en door de gebruikers van de zorg. Allemaal prachtig, zult u zeggen, en wat nu? Zonder een vertaling van dergelijke idealisti- sche beschrijvingen blijft het toch allemaal een beetje hemelfietsen. Maar juist in deze vertaling vind ik het HOOG-rapport heel goed geslaagd. De kern bestaat uit drie onderdelen:

1. Het vastleggen van beroepsrelevante taken, hier thema's genoemd.

2. Het vaststellen van bekwaamheidsniveaus.

3. IJkpunten.

De thema's zijn taakgebieden die voor elke gynaecoloog/obstetricus herkenbaar zullen zijn. Voorbeelden zijn de zwangerschapsbegeleiding, de bevalling en de perioperatieve zorg. In totaal zijn er achttien van deze taakgebieden geformuleerd. Het bekwaamheidsniveau wordt in vijf stappen onderscheiden en varieert van 'kennis hebben van' tot en met 'superviseert en onderwijst bij de handeling'. Daarbij zijn er drie ijkpunten: het einde van de beginfase (ongeveer twee jaar), het einde van de speciële fase (gedurende het derde en vierde jaar) en het einde van de integratie-/differentiatiefase (na het vijfde of zesde jaar). Vervolgens wordt aangegeven welke thema's wanneer op welk niveau beheerst moeten worden. Eenvoudiger en duidelijker kan het eigenlijk niet. Maar de vertaling gaat nog verder. Voor elk van de thema's is voor elke CANmeds-rol een invulling gegeven van mogelijke inhoud en vorm van toetsing. Bijvoorbeeld: voor het thema 'gecompliceerde bevalling' bestaat 'communicatie' uit 'rouw- en slechtnieuwsgesprek' en 'organisatie' uit 'triage en omgaan met de organisatie van 1e, 2 e en $3 e$ lijn en het kunnen runnen van de verloskamer'.

Met dit bouwwerk wordt een stevig fundament gelegd onder het onderwijs- en toetsprogramma in de opleiding voor de gynaecologie/ obstetrie. Het kompas is voor iedereen duidelijk, herkenbaar en eenvoudig te overzien. Het kan worden gebruikt om het formele onderwijs af te stemmen. Met de competentiekaart in de hand wordt in het HOOG-rapport geconstateerd dat 'medisch handelen' goed is uitgewerkt, maar dat 'samenwerking' en 'organisatie' onvoldoende zijn uitgewerkt. Werk aan de winkel dus. Ook komt een logische opbouw tot uitdrukking die verloopt van eenvoudige naar 
complexe taken, van veel supervisie naar zelfstandigheid.

Onderwijskundigen benadrukken het belang van het veel oefenen van relevante beroepstaken. Maar zonder enige vorm van verdieping van de oefening heeft herhaalde oefening niet veel nut. ${ }^{1}$ Verdieping wordt verkregen door reflectie op het handelen en door feedback. Met dit oogmerk lijkt ook het toetsprogramma in het HOOG-rapport te zijn vormgegeven. Veel gebruik wordt gemaakt van observatie van het feitelijke handelen met o.a. de Korte Klinische Beoordeling, de beoordeling van vaardigheden met de Objective Structured Assessment of Technical Skills (OSATS) en de beoordeling van gedrag door middel van $360^{\circ}$ feedback. Richtlijnen voor de frequentie van beoordeling worden gegeven. Daarnaast worden voortgangstoetsen gebruikt om het cognitieve domein te evalueren. Uitdrukkelijk is het toetsprogramma gericht op feedback. Gelukkig kiezen we in Nederland niet voor de Amerikaanse weg waarin vooral de nadruk ligt op certificering en dus op examens. Met het HOOG-rapport wordt nog eens concreet gemaakt dat toetsen en leren sterk met elkaar verbonden (moeten) zijn. Er wordt zelfs gesteld dat het programma niet het meest geschikt is om de zwakkere aios te detecteren. Voorgesteld wordt dan ook om bij twijfel over te schakelen op een intensiever toetsprogramma dat op maat wordt toegesneden op de kandidaat met meer beoordelingsmomenten en met andere betrokken partijen. Een heel verstandige vorm van sequentiële toetsing. De geboden structuur vormt een uitstekende basis om een portfolio te vullen. Portfolio's hebben geen enkele zin als ze geen duidelijke leerwaarde hebben en op een of andere manier met iemand gedeeld worden. Het portfolio is in het HOOG-rapport een verzamelinstrument dat gebruikt wordt om voortgangsgesprekken te voeren: vier in het eerste jaar, twee in het tweede jaar en één in de laatste drie jaren. De aios bereidt dit gesprek voor met behulp van het portfolio, maakt een zelfinschat- ting (vragenlijst wordt beschikbaar gesteld), bespreekt dit alles met zijn begeleider en maakt een plan voor de volgende periode. Aan de hand van het portfolio heeft de begeleider een indruk welke bekwaamheidsniveau's worden bereikt bij welke thema's bij welk ijkingspunt.

Tot slot besteedt het HOOG-rapport aandacht aan de logistiek en tijdsbesteding en aan training van alle betrokkenen. De vaardigheid van het geven van feedback staat in dit laatste centraal.

Kortom, een helder, niet te ingewikkeld, herkenbaar en praktisch plan voor onderwijs en toetsing. Ben ik nou helemaal overtuigd door dit plan en ben ik optimistisch over wat er gebeuren gaat? Nou nee. Ik weet dat papier heel geduldig is en dat de implementatie van een onderwijsverandering de moeilijkste fase is van verandering. In zoverre is HOOG een ambitieus plan. Op alle mogelijke terreinen zal men nog op problemen stuiten. Daar ben ik niet optimistisch over. Grote onderwijsveranderingen duren jaren. De professionaliseringsslag die we bereikt hebben in de basisartsopleiding heeft zeker dertig jaar geduurd. We staan aan de vooravond van eenzelfde professionaliseringsslag in de vervolgopleiding. Of het ook zo lang zal duren weet ik niet. Een plan als HOOG markeert echter een goede start. Het is een prachtig kompas dat richting geeft aan een ontwikkeling, maar dat natuurlijk nog op de nodige klippen mag rekenen. Ik hoop in elk geval dat nog veel wetenschappelijke verenigingen met een dergelijk helder plan zullen komen.

Cees van der Vleuten

Universiteit Maastricht

\section{Literatuur}

1. Ericsson KA. Deliberate practice and the acquisition and maintenance of expert performance in medicine and related domains. Acad Med 2004;79(10 Suppl):S70-S81. 